\section{Reaping the benefits of no-tillage farming}

As president of the Howard G. Buffett Foundation, I am disappointed with the suggestion by Ken Giller, our partner in the nitrogen-fixation research programme N2 Africa, that the teaching of conservation agriculture in sub-Saharan Africa is "wholly misplaced" (Nature 483, 525-527; 2012).

Millions of growers, large and small, are reaping the benefits of no-tillage farming. It is one of the most cost-effective ways to protect and improve soil - a farmer's most precious asset. It builds soil fertility by increasing biological activity, reducing the need for fertilizers and minimizing their effects on the environment. It also reduces soil erosion, improves water quality, increases crop yields, helps to sequester carbon and reduces labour.

No-tillage farmers are growing crops on roughly 111 million hectares worldwide, including $70 \%$ of farmland in Brazil and Argentina. At Brazil's agriculturalresearch organization Embrapa, no-tillage farming is helping to unlock the agricultural potential of the vast Cerrado savannah, fuelling economic growth.

There are challenges in teaching new practices to smallholder farmers, and much work is needed to adapt no-tillage farming to Africa's diverse agroecological and socioeconomic environments. But with the proper research, training and capacity, it will be one of many tools African farmers need to increase productivity sustainably.

Howard G. Buffett Howard G. Buffett Foundation, Decatur, Illinois, USA. amk@hgbfoundation.org

\section{Protect the DNA of museum specimens}

We support Henry Nicholls' plea to unite museum exhibitions with behind-the-scenes research
(Nature 484, 36; 2012). But to avoid jeopardizing the scientific worth of collections, caution is needed if that research is done in molecular-biology laboratories under the same roof.

Museums store important, often irreplaceable, biological specimens. To protect the authenticity of their DNA, contamination must be prevented. Extraneous DNA amplified in a museum lab by the polymerase chain reaction can easily be transferred to collection storage areas unless strict safeguards are in place.

Protocols similar to those used for studying ancient DNA should be applied to the development and operation of molecularbiology labs within museums. For example, the labs should be in a separate building, with a one-way flow of people and consumables from the collection area to the lab. Lara Shepherd, Leon Perrie Museum of New Zealand Te Papa Tongarewa, Wellington, New Zealand.

lara.shepherd@tepapa.govt.nz

\section{China's bear farms prompt public outcry}

Some 10,000 bears are farmed in China to procure their bile for traditional Chinese medicine. This cruel practice has stimulated a wave of condemnation across the country.

Bile is repeatedly collected from live bears through a surgically introduced opening into the bile duct, a procedure that is painful and distressing to the animals (see www. animalsasia.org). Some pharmaceutical companies use a variation of this technique that they say does not hurt the bears.

Even though the ursodeoxycholic acid found in bear bile has been available in synthetic form for decades, many wealthy patients prefer the natural product. Despite the disputed health benefits of bear bile, this has been an incentive for companies to promote bear farming.

The animal-welfare organization Animals Asia Foundation, headquartered in Hong Kong, has been a pioneer in challenging the bear-farming industry. It was recently accused of undermining traditional medical practices by the Chinese Association of Traditional Chinese Medicine. After 10 years of fighting alone, the foundation's work now has strong public backing. Many delegates at the National People's Congress last month declared that the industry should not be tolerated in a modern civilized society (see go.nature.com/ vg96sd; in Chinese).

China needs to promote substitutes for bear bile through further campaigning and public education. Legislation should be introduced for an animal welfare bill, which might eventually lead to a ban on bear farming.

Xia Sheng, Haolin Zhang, Qiang Weng College of Biological Sciences and Biotechnology, Beijing Forestry University, China. qiangweng@bjfu.edu.cn

\section{Validate gene findings before telling donors}

You report on recommendations that US biobanks should make participants in genome studies aware of incidental findings about their own DNA that might be medically relevant (Nature 483, 373 and 387; 2012). But assigning participants access rights to research that is not validated could be putting the cart before the horse.

Incidental findings about an individual's gene variants need to be verified analytically before being returned to the DNA donor (S. M. Wolf et al. Genet. Med. 14, 361-384; 2012). Even if a variant is accurately defined, further evidence of both clinical validity and utility are needed if its discovery is to be meaningful.

It would be irresponsible to follow the recommendation of Wolf et al. to communicate to the research subject the finding of one genotype variant when there may be hundreds of others related to the same phenotype, or when the phenotype varies with ethnic or environmental differences.

Investigations would be needed into whether evidencebased prevention or treatment is available for the particular gene finding, as well as into the reliability of genetic counselling based on complex, often ambiguous, risk information.

DNA donors should be informed that incidental findings must first be confirmed and translated into clinical application before information is communicated to them. We cannot side-step the process of proving clinical utility.

Mats G. Hansson Centre for Research Ethics \& Bioethics, Uppsala University, Sweden. mats.hansson@crb.uu.se

\section{Enhance visibility of India's academies}

Policy-makers must take bold measures to improve the standing of Indian science (Nature 484, 159-160; 2012), but it is important that the country's scientists own up to their responsibility for the current state of affairs.

Take India's science academies. Because they wield little apparent influence on science, policy or society, they are largely invisible to scientists and to the public. Their relevance seems to be limited to making annual awards to a few scientists who publish their work in journals with high impact factors. It is time for these academies to wake up to the challenge and become scientifically and socially important.

Abhay Sharma CSIR-Institute of Genomics and Integrative Biology, Council of Scientific and Industrial Research, Delhi, India. abhaysharma@igib.res.in 